\title{
Managing the Limbe Floods: Considerations for Disaster Risk Reduction in Cameroon
}

\author{
Roland Ndille $\cdot$ Johannes A. Belle
}

Published online: 11 June 2014

(c) The Author(s) 2014. This article is published with open access at Springerlink.com

\begin{abstract}
Cameroon has recorded disasters, both natural and man-made, in the past. The coastal city of Limbe and many other geographical locations are potential sites for future disasters. On the basis of interviews and related primary and secondary literature, this article looks at past occurrences of floods in Limbe, particularly those of 2001, and how the state and local authorities managed the challenge. Through this, it attempts an evaluation of state policies and the institutional structure for disaster risk reduction (DRR) and management in the country. The study reveals that Cameroon does not have a national disaster management structure and a national platform for DRR. Disaster related activities are lumped together with other civil protection responsibilities of the Ministry of Territorial Administration and Decentralization (MINATD) despite the country's commitment to the Hyogo Framework for Action 2005-2015. Government interventions are more reactive than proactive although its strategy to disaster management indicates both disaster preparedness and emergency intervention and rehabilitation. The study concludes that the present strategy is bureaucratic, financially burdensome, and does not really achieve the essential goals of DRR in saving lives and reducing vulnerability. For DRR to be effective in Cameroon, a permanent disaster management unit with regional and local structures should be put in place independent of other branches of the Department of Disaster and Emergency
\end{abstract}

\section{R. Ndille}

Faculty of Arts, University of Buea, P.O. Box 63, Buea, SWR, Cameroon

\section{J. A. Belle $(\bowtie)$}

Disaster Management Training and Education Centre for Africa, University of the Free State, Bloemfontein 9300, South Africa e-mail: belleja@ufs.ac.za
Services of MINATD and with each level exercising a significant degree of operative autonomy. A national policy and framework with emphasis on DRR should be adopted in the country.

Keywords Cameroon - Disaster risk management $\cdot$ Disaster risk reduction . Flood · Landslide

\section{Introduction}

A disaster is a serious disruption of the functioning of a community or a society involving widespread human, material, economic, or environmental losses and impacts that exceed the ability of the affected community to cope using its own resources (Wisner et al. 2004; Birkman 2006; UNISDR 2009; Coppola 2011). The number and seriousness of disasters in terms of people affected and property lost have been on the increase around the world since the 1960s when reliable data started to be recorded (DFID 2006). Between 2000 and 2012, disasters killed 1.2 million people and affected an annual average of 268 million people. Disasters also caused damages worth USD 1.7 trillion between 2002 and 2012 (Guha-Sapir et al. 2013; UNISDR 2013).

Preparedness and relief activities have often shown the extent of the effects of disasters. That is why local, regional, national, and international organizations have often been on the alert, ensuring that effective and well prepared disaster management plans are made available in vulnerable areas for prevention, preparedness, rapid and effective relief, and recovery. Cameroon has experienced a number of natural and man-made disasters over the years and the approach to solving the crises by bringing relief to the affected population has left many people uncertain of 
the availability and approach to disaster management in the country. A paucity of research literature on disaster management in Cameroon adds to the problem. An in-depth study of the history of disasters and disaster management in Cameroon has become imperative. The aim of this study is to contribute to the historiography of disaster management in Cameroon and to create awareness of the necessity to regularly question and assess policies and actions in managing disasters.

\section{Study Area}

Cameroon is a democratic republic with a surface area of $475,000 \mathrm{~km}^{2}$. Recent estimates (2012) put the population at about 22 million people (African Development Bank 2013). Although the estimates indicate a moderate population density of 46 people per $\mathrm{km}^{2}$, the rural-urban population divide shows that $59.9 \%$ of the population lives in urban areas while $40.1 \%$ lives in rural areas (UNISDRAfrica 2010). The population density is thus uneven and particularly intense in the urban areas. This exacerbates the quest for basic services such water, electricity, and other social amenities like appropriate housing, invariably leading to the development of slums and ghettos thereby increasing vulnerability to disasters. It is estimated that between $70 \%$ and $80 \%$ of the urban population lives in slums with access to portable water limited to only $37.5 \%$ (Nussbaum 2010). This situation is made even worse by the fact that almost a half of the country's population lives below the poverty line and unemployment currently stands at $30 \%$ (CIA World Factbook 2013). The lack of money and the need to sustain livelihood by any means ultimately lead to the lack of a culture of safety and disaster prevention among this portion of the population.

In 2012, the country's annual growth rate was $4.1 \%$ and the GDP per capita stood at USD 2,400. The national budget balance grew in deficit from $2.7 \%$ in 2011 to $3.5 \%$ in 2012 of the GDP and inflation stood above $3 \%$ (African Development Bank 2013). All these in addition to the fact that the country over the past 10 years has featured prominently amongst the most corrupt nations in the world (Transparency International 2013) emphasize the difficulty on the part of the government and other local stakeholders of finding resources for disaster management and putting them into effective use.

Cameroon is divided into 10 administrative regionstwo (the North-West and South-West) are part of the former British administered territory of Southern Cameroons and the eight others are part of the former French administered territory of Cameroun. The country can also be divided into a Christian south and Muslim north, and forested south and savanna north. There are more than 260

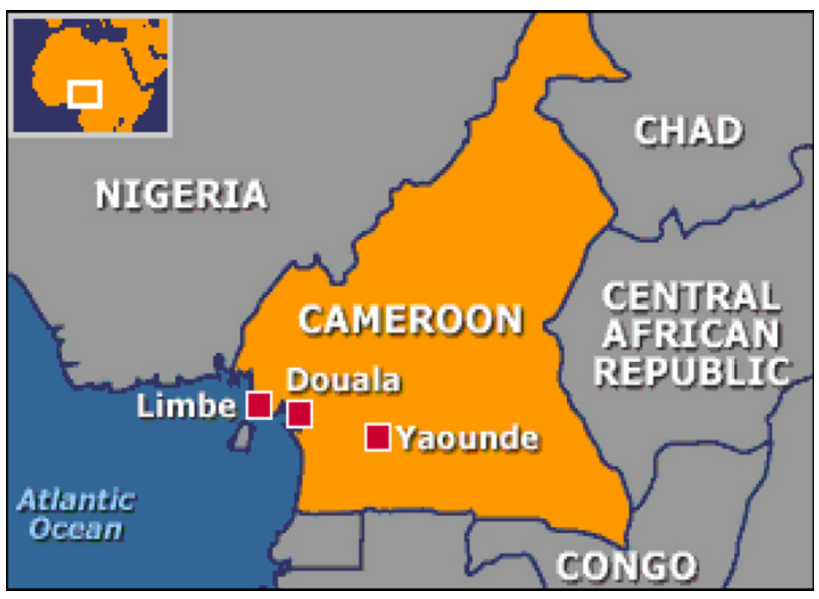

Fig. 1 Geographic location of Limbe in Cameroon. Adapted from Kometa (2012)

ethnic groups, each speaking a different dialect (Neba 1990). The country has abundant natural resources ranging from fertile soils for agriculture, oil and gas, minerals such as gold, bauxite, and tin, to timber and other non-timber forest products. Since the 1990s, due to the extraction of oil off the coast of Limbe in the Gulf of Guinea, the country's economic emphasis to some extent has shifted from agriculture to the extraction of oil and gas but revenues from the exploitation of these resources, and from oil in particular, have not been sufficiently channelled into structural investments in infrastructure and the productive sectors (African Development Bank 2013).

The city of Limbe is located along the coastal area of Fako Division, South-West Region of Cameroon (Fig. 1). The indigenous people include the Bakweri, Isubu, and Creoles (Matute 1988). It has beautiful coastal beaches, historic monuments, a botanic garden, and a wildlife center. It is not only an international tourist destination but the major petroleum and agricultural hub of Cameroon. The lone oil refinery is located in Limbe and the Cameroon Development Corporation's (CDC) banana, palm, and rubber plantations are spread over a majority of the most favorable lands for settlement around the city. The Corporation also has its headquarters in Limbe. The city's economic importance therefore cannot be overemphasized and this continues to account for the high influx of economic migrants who then exert pressure on the city's already scarce natural and man-made resources. With a surface area of $545 \mathrm{~km}^{2}$, and a population currently estimated at 120,000 inhabitants (Mosoke 2012), Limbe has one of the highest population densities in Cameroon with 220 people per $\mathrm{km}^{2}$.

The city is characterized by a low-lying coastal plain, rising to a chain of horseshoe shaped hills with slopes of 


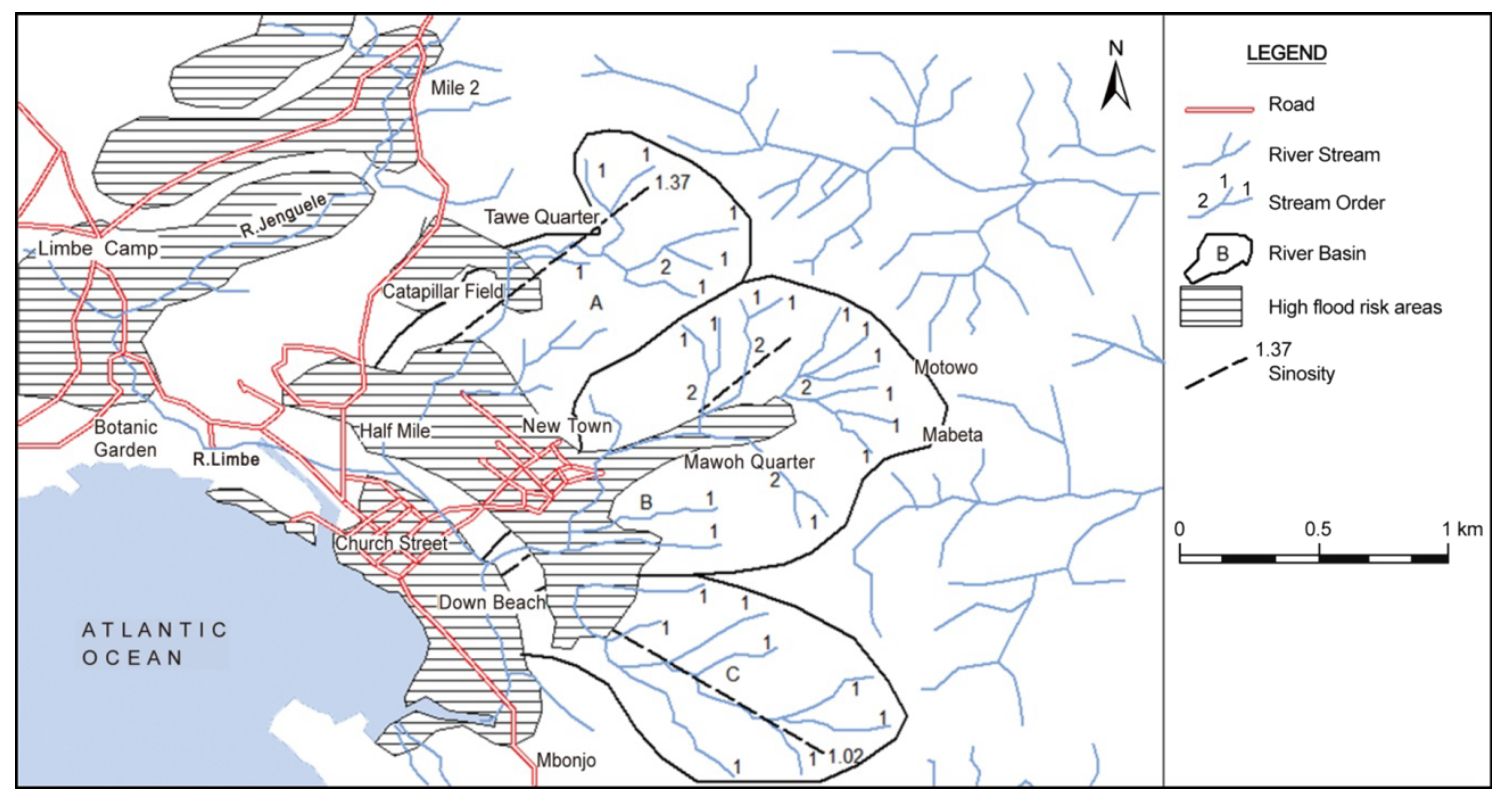

Fig. 2 High flood risk areas in Limbe, Cameroon. Adapted from Kometa (2012)

varying intensities towards the northeast and east, with the highest points reaching $362 \mathrm{~m}$ above sea level (Njabe and Fobang 2006). The area exhibits the characteristics of the Gulf of Guinea tropical equatorial climate of hot, moist, and dry conditions (Folack and Gana 2003). Only about 10 miles from Dibuncha, the second wettest place in the world after Cherrapunji in India (UNU-EHS and UFS-DiMTEC 2010), Limbe experiences very heavy torrential rains in the long rainy season (March-October) with the highest average monthly precipitation of about $700 \mathrm{~mm}$ recorded in June, July, and August (Neba 1990).

A drive through the city indicates an acute spatial disorganization with a mixture of planned and unplanned settlements, which are a reflection of a relative scarcity of suitable land for settlement as a result of rapid population growth and a lack of any effective land use development plan. This is because, possibilities of expansion are limited by the hilly nature of the eastern side, the Atlantic ocean to the south, the Mt. Cameroon lava flow route to the west, and the plantations of the CDC to the north. The imminent construction of a deep seaport facility and a naval shipyard has not only exacerbated population influx but has further intensified land speculation. Within the city small streams flow into larger drainage beds that converge into two main rivers (Limbe and Jenguele) that empty into the Atlantic Ocean (Fig. 2). These rivers frequently overflow their banks in the rainy season causing floods in the low-lying areas that are just 1-2 $\mathrm{m}$ above sea level. These are ideally the best parts for settlement but unfortunately there are no properly conceived drainage channels throughout the city. The situation is aggravated by settlement very close to the coastline at sea level with very poorly constructed, mostly wooden buildings. The hills that surround the city are made up of loose ferralitic and volcanic soils that easily disintegrate when they absorb a lot of water (Nwankiti 1983).

Poverty affects over $85 \%$ of the Limbe population (Awum et al. 2001). That is why over $70 \%$ of the population of Limbe lives in make-shift temporal structures constructed on floodplains, too close to the coastline, or on the hillslopes (areas declared as not suitable for habitation) and under slum-like conditions-a situation of high vulnerability to disaster (Mosoke 2012). The intense seismic activity from Mt. Cameroon located in the nearby Buea Subdivision and the threat of lava flows into the city have made matters worse. The last eruption of Mt. Cameroon in 1999 emitted hot magma that burnt down a large section of a palm plantation and the closest magma solidified just a few kilometers from the city. All these, make Limbe a city highly vulnerable to disasters.

\section{Methodology}

This study is qualitative and makes use of a blend of relevant historical inquiry and social science data gathering tools and presentation approaches. The researchers have relied heavily on oral accounts of hazard related experiences and data from primary and secondary written sources. Interviews were conducted in the neighborhoods affected by floods and landslides between February and June 2012, with affected persons and other eyewitnesses as well as some staff of the Limbe City Council, social 
workers, and some members of the 2001 Local Crisis Commission for the 2001 flood and landslide disasters in Limbe. A total of 50 participants were interviewed by convenience sampling on a one-to-one, non-directive basis (Maree 2009). The data were analyzed by grouping the responses into thematic areas and presented in a narrative format.

Archival data from committee reports and legislations on disasters were obtained from the National Archives in Buea (NAB), National Archives in Yaoundé (NAY), the Ministry of Territorial Administration and Decentralization (MINATD), and the Limbe City (former Urban) Council (LCC). These materials gave the researchers a view of the past and present policies on disasters in the country. Published books and internet sources provided us with general, theoretical, and conceptual knowledge of the field of study. For a first-hand impression of the floods, landslides, and drainage situation in the city during the rainy season and to enable us corroborate the oral and written data, we also carried out field observations in the city in June, July, and August 2013. We recognize, however, that major sources of error for research reporting could arise from the authentication of sources and from the subjective bias of the authors. We therefore ensured that all respondents confirmed their statements by sending them feedback from the interviews before using them in the study. To enhance objective research reporting a wide variety of informants and documents were consulted.

The hypothesis is that the Cameroon government has not set up an efficient disaster risk reduction (DRR) framework and that current strategies are very inefficient. The objectives are to analyze the government's handling of contemporary flood and landslide situations in Limbe; to show the inefficiency of the current strategies; and to highlight the need for a reconsideration of government strategies with the ultimate goal of establishing an efficient proactive national DRR framework that is completely autonomous from the current reactive civil protection structures of the MINATD.

\section{Contemporary Flood Disaster Events in Limbe and the Government's Response}

Despite the awareness that some of the low-lying areas in Limbe are not habitable, many people in the last two decades have adopted a resigned attitude toward this and also have encroached on the steep hillslopes known for their catastrophic landslides (Mosoke 2012). The consequences have often been grievous. Each year, between the months of June and August, often characterized by weeklong torrential rains, the city is submerged in water, above a meter deep in some quarters, causing serious distress to
Table 1 Impact of floods and landslides in Limbe, Cameroon

\begin{tabular}{lrrrrr}
\hline Item & 1990 & 2000 & 2001 & 2007 & Total \\
\hline Displaced households & 32 & 79 & 233 & 63 & 407 \\
Deaths (human) & 10 & 14 & 93 & 12 & 129 \\
Reported health cases & 19 & 20 & 197 & 62 & 298 \\
Buildings destroyed & 16 & 33 & 154 & 83 & 286 \\
Animals/fowls lost & 206 & 147 & 835 & 244 & 1,432 \\
People rendered unemployed & 51 & 107 & 438 & 79 & 675 \\
Roads and bridges damaged & 7 & 5 & 19 & 4 & 35 \\
Electricity/water installations & 15 & 8 & 54 & 6 & 83 \\
$\quad$ damaged & & & & & \\
\hline
\end{tabular}

Limbe Urban Council (2000, 2001) and Andin (2012)

the local population and great embarrassment to the municipal authorities and local government officials. Residents on the slopes find the hills collapsing on their houses. According to statistics, each year about 100 homes are flooded and an average of five landslides occurs in the city (Lyonga 2012). In some years the situation became so critical that it required national emergency alerts-such as in 1990, 2000, 2001, and 2007. Emphasis in this analysis is on the 2001 disaster because of its devastating nature and the fact that it received significant government attention from which state disaster management strategies could best be appreciated.

On 26 and 27 June 2001 the city was engulfed in heavy rains that led to a combination of floods and landslides and resulted in more than 30 landslide scars, several tensional cracks (Lambi et al. 2002), 154 completely destroyed houses, and rendered over 233 people homeless. About 93 people died and over 197 cases were reported for postdisaster related illnesses and wounds of which 82 were reported at the Limbe District Hospital alone (Andin 2012). A significant number of livestock was lost and many people were rendered permanently or partially unemployed. The floods and landslides took a great toll on community infrastructure such as roads, water and electricity supply lines, communication systems, schools, hospitals, and churches, which were either completely or partially shattered. All losses were estimated at about three million US dollars (Limbe Urban Council 2001). A comparative summary of the damages caused by floods and related landslides in Limbe since 1990 is presented in Table 1.

When disasters occur as they have in Limbe, it is expected that relief and rehabilitation would be swift. In 2001, the Senior Divisional Officer for Fako Division through the Governor of the South-West Region informed the various administrative levels of the situation as policy demanded. Through Prefectoral Order No. 94/2001 of 27 June 2001, the Senior Divisional Officer set up a crisis 
commission that comprised of several subcommittees. The Crisis Commission included the Delegate of Town Planning and Housing, Fako; the Divisional Delegate for Mines, Water and Energy; a representative of the Divisional Officer for Limbe; the Divisional Delegate of Public Works; the Mount Cameroon Project ${ }^{1}$; the Limbe Botanic Garden; the Delegate of Urban Affairs, Limbe; the Delegate of Environment and Forestry; the representative of the CDC; the local Red Cross officials; the representatives of the Bimbia and Bonadikombo Development Councils; Forces of Law and Order; and the Department of Geology at the University of Buea (Limbe Urban Council 2001).

The Crisis Commission rallied a team of 725 persons, of which 230 were volunteers from humanitarian and charitable organizations. Financial resources of USD 65,000 equivalent and material resources of 15 trucks, two caterpillars, 14 assorted vehicles, and many others began to arrive Saker Baptist College, which was transformed into an emergency center as the students had gone on holidays 2 days before. Relief workers began to move destitute survivors from the affected areas to the college. Truckloads of bags of rice, beans, potatoes, onions, vegetables, oil, milk, meat, fish, bread, basic drugs, mattresses, clothes, bed sheets, pillowcases, tents, coffins, and so on continued to flow in from all directions as the affected persons were being moved and the dead buried (Lyonga 2012). The Minister of Territorial Administration and Decentralisation, who is responsible for civil protection, arrived Limbe a few days after.

Apart from immediately assisting victims of the floods and landslides, to prevent post-disaster crises such as the spread of epidemics like cholera, the Crisis Commission was expected to determine ways of rehabilitating and reconstructing the Limbe Municipality; identify the risk zones; define unhabitable areas; propose strategies for drainage in the city; and make general recommendations to minimize potential risks. After the floodwaters had receded, the Commission went around the city to identify the affected areas and assess the level of damage in a disaster assessment exercise. After the assessment tour they began paying compensation to the victims and launched rehabilitation and resettlement works.

Damaged roads, water channels, and bridges that had collapsed and completely cut off some neighborhoods from the rest of the city were gradually reconstructed. Rehabilitation also involved the dredging and widening of the stream channels and the construction of reinforced concrete embankments on the streams. Tarred roads heavily destroyed by floodwaters were also rehabilitated while

\footnotetext{
${ }^{1}$ An international nongovernment organization involved in research and the preservation of forest, wildlife, and environment around the Mt. Cameroon area that includes Limbe.
}

gravel was thrown on the earth roads (Lyonga 2012).These huge financial engagements notwithstanding, the government disbursed another USD 1.5 million to identify risk zones and evacuate the occupants. About 150 ha of land were provided by the Limbe Urban Council for resettlement to this effect in the Bonadikombo area on the northern outskirts of the city. By the beginning of 2002 the government had begun to construct low-cost houses in this area. The last activities from the recommendations of the 2001 Crisis Commission were carried out by the Limbe Urban Council in 2005. In collaboration with the Divisional Officer of Limbe the Council began demolishing houses and structures within the municipality built on waterways. These structures were said to have been obstructing the flow of rainwater causing floods during the rainy seasons. Structures constructed on hillslopes were also targeted (Mosoke 2012). These efforts notwithstanding, the floods of 2007 with relatively serious impacts as well came to prove to the government that there is much more to be done in disaster management than existing relief and rehabilitation strategies can accomplish.

\section{Assessing the Legal and Institutional Frameworks for Disaster Management in Cameroon}

Until September 1986, when the Lake Nyos gas emission disaster struck Cameroon, the country had not thought of a disaster management policy or strategy. The magnitude of this disaster in which 1,785 people were killed (Ayanji 2004) demonstrated to the government that it was time to act. The government passed Law No. 86-16 of 6 December 1986 to reorganize civil protection in Cameroon (Republic of Cameroon 1986). Despite this law, it was only after 10 years following the 1996 measles outbreak with over 53 lives lost in Wum in the northwest region not far from the scene of the 1986 disaster and the cholera epidemic in northern Cameroon, which began in 1992 and by 1996 had killed over 440 people (Ayanji 2004) that the state began to act concretely. The President of the Republic signed Decree No. 96/054 of 12 March 1996 to determine the composition and duties of the National Council for Civil Protection (Republic of Cameroon 1996) and followed this up 2 years after by Decree No. 98-31 of 9 March 1998 to determine the organization of emergency and relief plans (ex post disaster measures) (Republic of Cameroon 1998a); and Law No. 98-15 of 14 July 1998 relating to establishments classified as dangerous, unhealthy, or obnoxious (Republic of Cameroon 1998b).

These, alongside Decree No. 2004/99 of 26 April 2004 to reorganize the MINATD (Republic of Cameroon 2004), Decree No. 2004/320 of 8 December 2004 and Decree No. 2005/104 of 13 April 2005 (Bang 2013), have since been 
Table 2 Structure of disaster response in Cameroon

\begin{tabular}{|c|c|}
\hline Government organ & Duties \\
\hline $\begin{array}{l}\text { PRESIDENCY OF THE } \\
\text { REPUBLIC (The National } \\
\text { Commission on Civil } \\
\text { Protection, NCCP) }\end{array}$ & $\begin{array}{l}\text { Defines policies, sets up the } \\
\text { NCCP; harnesses national and } \\
\text { international relief efforts }\end{array}$ \\
\hline MINATD (DDES) & $\begin{array}{l}\text { National supervisory authority of } \\
\text { relief efforts; custodian of } \\
\text { national disaster and } \\
\text { emergency fund }\end{array}$ \\
\hline $\begin{array}{l}\text { REGIONAL GOVERNORS } \\
\text { (Economic and Social Service; } \\
\text { Regional Delegation of Social } \\
\text { Affairs) }\end{array}$ & $\begin{array}{l}\text { Coordinates disaster relief at the } \\
\text { regional level }\end{array}$ \\
\hline $\begin{array}{l}\text { SENIOR DIVISIONAL } \\
\text { OFFICERS (Divisional } \\
\text { Delegation of Social Affairs) }\end{array}$ & $\begin{array}{l}\text { Supervisory authority at the } \\
\text { divisional level, sets up local } \\
\text { crisis commission with the } \\
\text { approval of the Regional } \\
\text { Governor }\end{array}$ \\
\hline $\begin{array}{l}\text { Subdivisional Officers/Municipal } \\
\text { Councils/Local NGOs, and so } \\
\text { on }\end{array}$ & Implement relief efforts \\
\hline
\end{tabular}

the operating legal frameworks for civil protection under which any disaster management effort is carried out. While Decree No. 2004/320 made civil protection the second most important function of MINATD, Decree No. 2005/104 transformed the Department of Civil Protection in MINATD to the Department of Disaster and Emergency Services (DDES) and gave it the responsibility to organize and coordinate civil protection activities throughout the country for natural and human induced disasters. Table 2 summarizes the structure of disaster response in Cameroon.

By virtue of this legal and institutional framework, the President of the Republic, assisted by the National Council for Civil Protection, defines policies of disaster risk management, and such policies are implemented by MINATD, through the DDES (formerly the Department of Civil Protection). This national structure is further supported by the regional governors as well as the regional and divisional services of the specialized ministries such as the Ministry of Environment and Nature Protection and the Ministry of Social Affairs. This structure shows a "top down" approach to disaster management with the effect that implementation is bound to be delayed by bureaucratic and administrative bottlenecks. From the Presidency to the ministerial departments, down to the regional governors and delegations, and further down to the divisional officers and divisional delegations, and ending with the local civil and municipal administrators, subdivisional officers and mayors, it takes a significant amount of time to have disaster management related decisions to be made or for relief efforts to reach the concerned.
In the event of a disaster the competent divisional/subdivisional civil administrator with reliable and irrefutable information on the nature and scope of the disaster informs the Regional Governor, who also informs the Minister of Territorial Administration and Decentralization. S(he) also relays the Prime Minister, who then informs the President. Authorization then leaves the Presidency following the same channel before the local administrative officer concerned can send out an alert; initiate emergency relief activities; mobilize the necessary human, material, and financial resources; convene a crisis commission; and inform the general public.

The convened crisis commission then assumes the responsibility of coordinating public relief action; directing relief operations; preparing rescue facilities; forwarding relief to the disaster area; determining the assistance and relief needs of victims; assessing the immediate and after effects of the disaster; and managing all the human, material, and financial resources provided for the circumstance by the government authorities, public, or private international organizations and, in general, all gifts and legacies.

From the above description and with the experience of the 2001 Limbe floods and landslides, it can be observed that practically, the disaster management strategy of the Cameroon government is centered on providing postdisaster relief and rehabilitation rather than on being proactive and preventive. Where the government strategy has shown a leaning towards some disaster preparedness efforts, they have remained theoretical than practical. For instance although Law No. 86-16 of 1986 to reorganize civil protection provides for the setup of a national observatory for disasters with local branches to permanently monitor disaster-prone areas, this organ has not yet been set up 28 years after this law was enacted. Also, in 2002, the government set aside March 1 to be observed yearly as the National Day for Civil Protection and for more than 10 years has observed the International Day for Disaster Reduction on 9 October. The events on these days, contrary to expectation, make no significant impact in terms of disaster awareness and preparedness as they are often characterized by speeches by government officials instead of grassroots sensitization campaigns.

In Limbe in 2012, of the 50 people sampled for this study, only 21 indicated that they were aware that the area where they lived was a disaster-prone area despite their regular experiences with floods and landslides. Forty-eight indicated that they have never heard of a talk on Limbe as a disaster-prone city while only seven indicated that they have been met by a local NGO worker, municipal or government official on a door to door sensitization campaign related to disaster prevention. Five of these seven however revealed that such an authority only came to serve 
them a demolition notice and not for any disaster risk education. There is also an annual report on the state of civil protection in Cameroon but the extent of its dissemination to zones and people concerned remains questionable. None of the 50 participants has ever heard, seen, or read a portion of this document. These revelations clearly demonstrate the lack of focus of the government strategy towards DRR in the country despite the fact that partners such as the United Nations Development Programme (UNDP), the United Nations Office for the Coordination of Humanitarian Affairs (UNOCHA), and ProVention Consortium have expressed their willingness to cooperate in this domain. In terms of national risk identification, assessment, monitoring, and early warning, a general study was conducted in 1999 in hazard-prone areas (UNISDRAfrica 2010) but this study, from the level of awareness in Limbe, either passed the people by or begs for a second phase.

Judging from the level of casualties, material, psychosocial, and infrastructural damages (most often irreparable) that disasters inflict on individuals, communities, and governments, reactive post-disaster strategies such as those currently in place in Cameroon should be discouraged as they do not meet the objectives of DRR of saving lives and reducing vulnerability. The administrative bureaucracy involved in sounding a disaster alert makes intervention slow, stressful, and increases the level of casualties and damages. Although the current civil protection structure seems decentralized by involving municipalities and divisional as well as subdivisional delegations of the concerned ministries, the devolution of authority to lower administrative levels is limited in practice (Bang 2013). For example, Law No. 2004/018 of 22 July 2004 stipulates that municipal councils are responsible for such tasks as organizing and coordinating relief operations (Bang 2013). But they must await authorization and approval from higher administrative levels, the immediate one being the Senior Divisional Officer. As the local authorities await authorization to come down the chain of command, the disaster continues to claim victims.

Experience from the Limbe disasters has demonstrated that post-disaster activities such as compensation and rehabilitation are hardly successfully carried out. The 2001 Local Crisis Commission was dissolved sometime in 2002 (Andin 2012) when it was not certain that it had fulfilled its terms of reference and without a proper auditing of its accounts. Besides, it has become very difficult to hold commission members accountable after the commissions have been dissolved. The Commission was made up of civil servants, some of them novices in disaster management and a majority must have been transferred to other localities considering the fact that such officials hardly stay in one station for up to 5 years. The fact that disaster field operations are managed by the Local Crisis Commission with lack of accountability discourages other agencies such as municipal authorities and NGOs from investing in DRR activities.

The finances for the implementation of the post-disaster management system come from the calamity budgetary head of the DDES in MINATD. This stands at USD 1 billion annually (UNISDR-Africa 2010). Often due to bureaucracy the finances are not disbursed on time although there is common knowledge that the first $24 \mathrm{~h}$ following a disaster are critical for search and rescue operations, which require a responsive disbursement of funds. Apart from that, there are no standards and norms of accountability for the use of relief resources. Where donations are made, as they were made in Limbe, the amounts collected are often poorly accounted for by local commissions. In most cases they are mismanaged. The 2001 Crisis Commission and the DDES have to date not informed the Cameroon public on the total amount of public and private financial and material donations received during the 2001 Limbe disaster and how they used the funds. Many of the victims still express feelings of disappointment with the 2001 Crisis Commission for mismanaging disaster relief resources. The situation in Limbe is not different from that of the 1986 Lake Nyos gas disaster as many of the victims are still waiting compensation from the government (Bang 2013). Cameroon was ranked the sixth most corrupt country in the world by Transparency International in 2004 and 144 out of 177 in 2013 (Transparency International 2013). The insurance system in Cameroon is very underdeveloped as well, implying that the government bears the brunt of rehabilitation and reconstructions, because private sector involvement in risk transfer is limited. Moreover, the roles of NGOs and the private sector are not indicated in the existing legislation. This limits their involvement to relief work when they are made part of crisis commissions.

\section{The Future: From Disaster Response to Disaster Risk Reduction}

At present, the overall coordination of the disaster management system in Cameroon lies with the DDES at the MINATD. This is the only nodal agency for disaster management in Cameroon. The intervention strategy of the DDES is expected to focus on three main complementary approaches. Before disasters, it is expected to promote disaster preparedness, prevention, and mitigation mainly through information, awareness-raising, sensitization, and education and other activities that would promote a culture of safety and readiness in the community-hence the establishment of contingency plans during the predisaster 
phase (Bang 2013). It is expected to initiate an emergency intervention plan during the crisis phase and coordinate the implementation of emergency response programs (sectoral contingency plans) for efficient and effective disaster management. Such activities include the on-the-spot coordination of emergency responses, search and rescue operations, and the supervision of the activities of local crisis commission. After disasters they are charged with performing activities relating to compensation and rehabilitation of affected populations, disaster and hazard risk assessment, reconstruction through the crisis commission, and the communication of risk zones. The approach so far indicates a marked disregard for the first phase, which unfortunately should be the one emphasized as it involves DRR.

It is important to emphasize that not all disasters, particularly natural disasters, can be prevented, but the risk of loss of life, injury, and damage to property can be mitigated with good evacuation plans, land-use planning, environmental management, and building codes or standards (Wisner et al. 2004; DFID 2006; UNISDR 2013). Cameroon should therefore adopt policies designed to provide permanent protection from disasters; any disaster-prone area should be equipped with disaster warning mechanisms; and the people need to be educated constantly on how best to carry out livelihood activities in such places. In January 2005, 168 governments including Cameroon adopted the Hyogo Framework for Action (HFA) 2005-2015 (UNISDR 2005), a 10-year global plan for natural DRR. It offers vulnerable communities such as Limbe guiding principles, priorities for action, and practical means for achieving disaster resilience.

Almost 9 years after the Hyogo Framework was adopted, very few of its recommendations are being applied in disaster-prone areas like Limbe in Cameroon. An examination of the extent of disaster preparedness in Limbe confirms this conclusion. After the June 2001 floods and landslides, the 2001 Local Crisis Commission identified the alignment of 30 landslide scars around the Mabeta neighborhood (Limbe Urban Council 2001). The people were informed of this after the disaster and some left the area but a majority has continued to live there. Since then, nothing has been done to inform the people of the dangers inherent in living around this area. Tremors from nearby and active Mt. Cameroon volcano can seriously affect this area and even reach the sea, where a tsunami could occur and hit the city.

In terms of disaster awareness and preparedness, it is observed that the level of disaster education in Limbe is very low. A survey carried out in the multi-hazards, disaster-prone areas of Limbe in 2010 (UNU-EHS and UFS-DiMTEC 2010) revealed that very little had been done to prepare the people for any impending disasters and to warn them to evacuate the areas before imminent disasters strike. Two years after, our sampling of the situation as indicated above reveal an even more alarming level of ignorance and unpreparedness. Limbe has no meteorological station to monitor and communicate rainfall, wind speed, and sea level to the people. The city remains highly vulnerable to disasters, as very few people have moved out of the disaster-prone areas of the city especially Mabeta, Motowo, Limbe Camp, Down Beach, and Church Street in the southern part of the city. The evacuation of these persons can only be achieved by a sincere government effort beginning with the local inhabitants being sensitized on dangers of living in such places. This can be achieved through local and international cooperation and partnerships.

The government of Cameroon must empower local communities and authorities to manage and reduce disaster risk through appropriate legislation; by providing access to the necessary information and resources; and through the employment of professionally trained man-power to effectively implement DRR policies. These basic tenets of DRR have yet to be realized in Cameroon as a whole and Limbe in particular. In a city with over $85 \%$ of the population affected by poverty, it is almost an impossibility to talk of the average inhabitant of the disaster-prone quarters buying a piece of land in a designated disaster-free area like Bonadikombo and constructing an average house of two bedrooms. Land speculation raised the cost of land to USD 7,000 for a $240 \mathrm{~m}^{2}$ plot and USD 10,000 for a $400 \mathrm{~m}^{2}$ plot (Awum et al. 2001). The cost of over USD 20 for $1 \mathrm{~m}^{2}$ of land is very high for the urban poor. The local municipality therefore must make available low cost housing facilities in disaster-free areas as a measure of risk reduction.

The poor road network and the absence of proper drainage facilities account for the poor harmony in rain water collection and the high level of flooding that the city registers in the rainy season. The municipality must make efforts towards infrastructural provision especially with regards to roads, gutters, and drains in Mabeta, New Town, Motowo, and Church Street and implement clean up campaigns to ensure that these structures are cleaned up and maintained on a regular basis. The indiscriminate building of houses in violation of town planning rules and regulations must be checked. Those built too close to the Jenguele River must be demolished and no more houses should be built along floodplains or hillslopes with landslide histories, especially on the Mabeta hills. Neither should any other type of landed property be located in disaster-prone areas. The invasion and occupation of vacant risky sites should be stopped; streams such as the Jenguele should be maintained and their channels kept wide enough to facilitate the quick evacuation of run-off 
waters through monthly clean-up campaigns. Projects for the upgrading of occupied floodplains and corresponding resettlement schemes should be prepared. Those that were started in 2001 in Bonadikombo should be completed and resettlement carried out there.

Measures should be taken to increase the vegetation cover in the city, especially around steep hillslopes to help reduce the speed of run-off water after rainfalls. Deeprooted trees should be planted on steep slopes and hillsides. The deforestation of slopes and steep hills around Limbe should be checked. There should be awareness and sensitization campaigns in Limbe, advising people on the negative consequences of dumping waste in drains as this eventually blocks their flow paths. The seashore must be reinforced with solid stones or block walls to avoid tidal overflow, and the removal of coastal mangroves should be regulated and checked. If the tides had been high on 26 and 27 June 2001, Limbe could have suffered more deaths. Government should set up permanent local emergency relief teams that can be activated in the event of an impending disaster. The municipality should also set up its own disaster management unit or service and equip it with the necessary human and material resources aimed at DRR.

At the national level, a strong political will is needed in Cameroon to gradually move from disaster response to disaster prevention, mitigation, and preparedness. The DDES, as the nodal disaster management agency, must have full-time paid staff who are experts in disaster management at national, provincial, as well as local levels. Their department must be linked to the research institutions of the Ministry of Scientific and Technical Research and Innovation, which would enable the disaster management structures to benefit from advice in land use, planning, and mapping of high-risk areas. A permanent disaster management structure should be put in place independent of other branches of the DDES, with regional as well as local organs each with a certain degree of operational autonomy. The structure must incorporate specific roles for each level of the disaster management structure, local administrative authorities, economic operators, and the public so that all can be held accountable for action or inaction.

When such structures are established, their sources of financing must be clearly defined and budgeting must lay emphases on DRR activities such as research, education, training, and public sensitization/awareness creation. The role of the Ministry of Finance and the Budget (though it is a member of the National Council for Civil Protection) must be evident in the legislations in ensuring that crucial financial resources are budgeted by all the ministries involved in disaster management. The keeping of historical records with the DDES relating to disaster risks is poor, and the information on disasters is often incomplete, especially in terms of statistics. This is a major problem that hampers research in this domain. The DDES and all agencies involved in disaster management in the country must also provide for a documentation and archives unit to meet the demand for the collection of systematic and accurate records.

\section{Conclusion}

The study aimed at assessing the Cameroon government's policies and practices on disaster management, especially in the context of the 2001 Limbe floods and landslides. The study revealed that although these disasters are a yearly phenomenon in the city of Limbe, regularly taking a heavy toll on human life, infrastructure, and material and financial resources, the government continues to rely on postdisaster relief and response policies and practices that were put in place after the 1986 Lake Nyos gas disaster. Other subsequent disasters have occurred in the country, notably the explosion of gas and petrol tanks in Nsam (1996), the Lagdo dam failure (1998), the eruption of Mt. Cameroon in Buea (1999), the landslides at Bafaka Balue (1997) and Lebialem (2009), the Ndop and Logone floods (2012), and a number of recorded epidemics, and bush and market fires (Ayanji 2004). Despite these numerous disasters and the heavy financial burdens they have been for the government, the state has not so far recognized the need to reform the national disaster management system.

The study concludes that the reform of the disaster management system in Cameroon is a matter of urgency and the application of the Hyogo Framework for Action five priority areas should now be seen as an urgent priority before the next calamity takes its toll on the people and their assets. Current climate change and the increase in extreme weather events should act as an impetus for the national government to put the disaster management function in Cameroon in line with international best practices. For example, South Africa adopted a national policy and framework for disaster management that emphasizes DRR without neglecting efficient and effective response (Government of South Africa 2002, 2005). Cameroon could follow the same example with basic adjustments to suit local needs. The state must ensure that DRR is prioritized and that strong institutional bases are created for its implementation at the national, provincial, and local levels. Structures must be put in place all over the country to identify, assess, monitor, and respond to disaster risks. This would enhance early warning and preventive actions. The use of knowledge, innovation, and education to build a culture of safety and resilience at all levels (UNISDR 2005) must be guaranteed through seminars, workshops, door-to-door as well as radio and television sensitization. Most importantly, where possible, the underlying risk 
factors must be reduced through resettlement, sustainable livelihoods, and effective environmental management. Disaster preparedness must be strengthened for effective response at all levels. The government's role as a policy developer, implementer, and evaluator is urgently needed.

Acknowledgments We have benefited from the field assistance (especially interviews) of Solange Enoh Andin, former student and supervisee of Roland Ndille in the Department of History at the University of Buea between 2009 and 2012. Immense thanks.

Open Access This article is distributed under the terms of the Creative Commons Attribution License which permits any use, distribution, and reproduction in any medium, provided the original author(s) and the source are credited.

\section{References}

African Development Bank. 2013. African Development Bank African economic outlook: Cameroon. http://www.afdb.org/en/ countries/central-africa/cameroon/cameroon-economic-outlook/. Accessed 12 Dec 2013.

Andin, S.E. 2012. Natural disasters and disaster management in the Limbe Municipality 1990-2007. Unpublished undergraduate long essay at the Department of History, University of Buea.

Awum, D., K. Bayie, and N.L. Fonda. 2001. Mainstreaming potentials for sustainable development in the Limbe Urban Municipality. Yaounde: PAFP.

Ayanji, E.N. 2004. A critical assessment of natural disaster management framework in Cameroon. Unpublished end of course research report at the Department of City Management and Urban Development, World Bank Institute, Rotterdam.

Bang, H.N. 2013. Governance of disaster risk reduction in Cameroon: The need to empower local government. Journal of Disaster Risk Reduction Studies 5(2): 1-10.

Birkman, J. (ed.). 2006. Measuring vulnerability to natural hazards: Towards disaster resilient societies. New York: United Nations University Press.

CIA World Factbook. 2013. Cameroon economy profile 2013. http:// www.heritage.org/index/country/cameroon. Accessed $12 \mathrm{Dec}$ 2013.

Coppola, D.P. 2011. Introduction to international disaster management, 2nd ed. New York: Elsevier.

DFID (Department for International Development). 2006. Reducing risk of disaster-Helping to achieve sustainable poverty reduction in a vulnerable world. A policy paper. Geneva: DFID.

Folack, J., and W.F. Gana. 2003. Cameroon: Project brief on the integrated management of the Limbe-Kribi coastal area. 4th draft.

Government of South Africa. 2002. Disaster management act. Act No. 57 of 2002. Cape Town: Government Gazette.

Government of South Africa. 2005. National disaster management framework. Durban: Lexis Nexis.

Guha-Sapir, D., P. Hoyois, and R. Below. 2013. Annual disaster statistical review 2012: The numbers and trends. Brussels: Centre for Research on the Epidemiology of Disasters.

Kometa, S.S. 2012. Ensuring human safety in the disaster prone town of Limbe Cameroon. Journal of Geography and Geology 4(2): $156-165$.

Lambi, C.M., S.S. Kometa, and L.F. Fombe. 2002. Environmental hazards and land use planning for sustainable development: The
Limbe unstable coastal region, Cameroon. In Instability: Planning and management; seeking sustainable solutions to ground movement problems, ed. R.G. Macinnes, and J. Jakeways, 151-160. London: Thomas Telford.

Limbe Urban Council. 2000. Report of the technical sub-committee on the 2000 floods. Limbe: Limbe Urban Council.

Limbe Urban Council. 2001. Report of the Crisis Commission of the 2001 flood and landslide disasters in Limbe. Limbe: Limbe Urban Council.

Lyonga, Casimir Njime. 2012. Personal interview. Civil engineer at the Limbe City Council. Limbe, 17 May 2012.

Maree, K. 2009. First steps in research. Pretoria: Van Schaik.

Matute, D.L. 1988. The socio-cultural legacies of the Bakweri of Cameroon. Yaoundé: Ceper.

Mosoke, Sebastine. 2012. Personal interview. Town planner at the Limbe City Council. Limbe, 15 April 2012.

Neba, A. 1990. Modern geography of the Republic of Cameroon, 3rd ed. Bamenda: Neba.

Njabe, R.K., and R. Fobang. 2006. Illustrated physical geography and map reading for Cameroon, 3rd ed. Limbe: Sunway.

Nussbaum, L. 2010. More than just a roof over my head. Cameroon: Housing for people living with HIV AIDS. http://www.thebody. com/content/art58858.html. Accessed 29 Apr 2014.

Nwankiti, O.C. 1983. Man and his environment. London: Longman Group.

Republic of Cameroon. 1986. Law No. 86-16 of 6 December 1986. On the reorganization of civil protection in Cameroon. National Archives in Buea.

Republic of Cameroon. 1996. Decree No. 96/054 of 12 March 1996. To determine the composition and duties of the National Council for Civil Protection. National Archives in Buea.

Republic of Cameroon. 1998a. Decree No. 98-31 of 9 March 1998. To determine the organization of emergency and relief plans (ex post disaster measures). National Archives in Buea.

Republic of Cameroon. 1998b. Law No. 98-15 of 14 July 1998. Relating to establishments classified as dangerous, unhealthy or obnoxious. National Archives in Buea.

Republic of Cameroon. 2004. Decree No. 2004/99 of 26 April 2004. To reorganize the Ministry of Territorial Administration and Decentralization. MINATD.

Transparency International. 2013. Corruption perception Index 2013. Berlin: Transparency International.

UNISDR (United Nations International Strategy for Disaster Reduction). 2005. Hyogo framework for action 2005-2015: Building the resilience of nations and communities to disasters. Geneva: UNISDR.

UNISDR (United Nations International Strategy for Disaster Reduction). 2009. Terminology. Geneva: UNISDR.

UNISDR (United Nations International Strategy for Disaster Reduction). 2013. Disaster impacts 2000-2012. Geneva: UNISDR.

UNISDR-Africa (United Nations International Strategy for Disaster Reduction Regional Office for Africa). 2010. Inventory of national coordination mechanisms, legal frameworks and national plans for disaster risk reduction in Africa. Nairobi: ISDR.

UNU-EHS and UFS-DiMTEC (United Nations University Institute for Environment and Human Security and University of the Free State Disaster Management Training and Education Centre for Africa). 2010. Vulnerability assessment of floods in the Limbe District of Cameroon. Presented at the Ph.D. block course held from 26 May to 2 June 2010 at DiMTEC, UFS.

Wisner, B., P. Blaikie, T. Cannon, and I. Davis. 2004. At risk: Natural hazards, people's vulnerability and disasters, 2nd ed. London: Routledge. 